DOI https://doi.org/10.32782/2305-9389/2020.23.08

УДК 94(477)“1931/1939”

Каранда Ірина,

завідувач кафедри гуманітарних дисциплін Львівського фахового коледжу харчової та переробної промисловості Начіонального університету харчових технологій

\title{
УЧАСТЬ ЗИНОВІЯ ПЕЛЕНСЬКОГО В РОБОТІ КОНГРЕСІВ НАЦІОНАЛЬНИХ МЕНШИН У 1930-Х РОКАХ
}

У статті проаналізовано ефективність участі відомого громадсько-політичного діяча, члена Українського національно-демократичного об’єднання (УНДО), посла польського сейму Зиновія Пеленського в роботі Конгресів національних меншин - міжнародної організації, яка в міжвоєнний період ХХ століття намагалася вирішити численні проблеми національних меншин. Зазначено, щзо у 1928 р. політик увійшов до Центрального комітету УНДО, проте віддав перевагу роботі в Ревізійному союзі украӥнських кооператив (УНДО) над партійною працею, щуо унеможливило його участь у роботі міжнародної організації. Тільки після обрання його послом сейму Другої Речі Посполитої у 1930 р. домінантною для нього стала робота над розбудовою иієі політичної сили. Окремий тогочасний напрям його діяльності-участь у роботі Конгресів національних меншин, де Зиновій Пеленський пропагував ідею соборності украӥнських земель та відстоював кониепцію «права нації на самовизначення». На конгресах начіональних меншин, політик виступав від не тільки від імені УНДО, але й представляв інтереси українців Галичини та Волині, які після 1923 р. зазнавали утисків та дискримінації від польської адміністрації в національно-культурній сфері. У період голодомору в Радянській Україні його виступи на міжнародній арені набули агресивних форм і спрямовувалися на критику радянської влади, яка приховувала масштаби голоду на Наддніпрянщині, блокувала міжнародну допомогу та загалом заперечувала факт масової смертності українців. Його вимоги територіальної автономії, виступи із соборницькими гаслами мали великий вплив на справу розв'язання украӥнського питання в міжвоєнний період XX cm., сприяли піднесенню авторитету як Зиновія Пеленського, так і УНДО.

Ключові слова: Конгреси начіональних меншин, Зиновій Пеленський, УНДО, Польщча, право начії на самовизначення.

\section{Karanda Iryna. Zinoviy Pelensky's participation in the work of Congresses of national minorities in the 1930s}

The article analyzes the effectiveness of the participation of a well-known public and political figure, member of the Ukrainian National Democratic Union (UNDO), Ambassador of the Polish Sejm Zinovy Pelensky in the Congress of National Minorities - an international organization that tried to solve many problems of national minorities. It is noted that in 1928 the politician joined the Central Committee of the UNDO, but preferred to work in the Audit Union of Ukrainian Cooperatives (UNDO) over party work, which made it impossible for him to participate in the work of an international organization. Only after his election as ambassador to the Sejm of the Second Rzeczpospolita in 1930 did work on building this political force become dominant for him. A separate area of his activity at that time was participation in the work of the Congresses of National Minorities, where Zinoviy Pelensky promoted the idea of the unity of the Ukrainian lands and defended the concept of "the nation's right to self-determination". At congresses of national minorities, the politician spoke not only on behalf of the UNDO, but also represented the interests of Ukrainians in Galicia and Volyn, who after 1923 were oppressed and discriminated against in the national and cultural sphere by the Polish administration. During the Holodomor in Soviet Ukraine, his speeches in the international arena took aggressive forms and were aimed at criticizing the Soviet government, which hid the scale of the famine in the Dnieper region, blocked international aid and generally denied the mass deaths of Ukrainians. His demands for territorial autonomy, speeches with conciliar slogans had a great influence on the solution of the Ukrainian question in the interwar period of the twentieth century, contributed to the rise of the authority of both Zinovy Pelensky and UNDO.

Key words: Congresses of national minorities, Zinoviy Pelensky, UNDO, Poland, the nation's right to selfdetermination.

Постановка проблеми. Зиновій Пеленський - відомий український політичний (з 1929 р. - член ЦК УНДО) та кооперативний (референт пропаганди Ревізійного союзу українських кооператив (РСУК); член Головної Ради краєвого господарського товариства «Сільський Господар», редактор «Господарсько-кооперативного Часопису» (1927-1930)) діяч, посол польського сейму (1930-1939), член низки громадських організацій - «Січ» (Відень), «Просвіта», Український Громадський Комітет Рятунку України тощо, неодноразово брав участь у роботі конгресів національних меншин. Його громадськополітична діяльність спрямовувалася на захист соціально-економічних та національно-культурних інтересів українців Галичини в умовах польського владного режиму міжвоєнного періоду XX ст. 
Аналіз публікацій. Громадсько-політична діяльність 3. Пеленського, зокрема його участь у роботі конгресів національних меншин, не розглядалася спеціально українськими та зарубіжними вченими. Окремі фрагменти його політичної біографії здебільшого відображено в узагальнюючих наукових працях, які стосуються суспільно-політичних, соціально-економічних процесів у Другій Речі Посполитій (виняток - праця Т. Гелей та С. Гелея [3]). Джерельну основу статті становлять матеріали Державного архіву Львівської області, спогади сучасників, а також публікації в провідних галицьких часописах.

Мета статті - охарактеризувати особливості громадсько-політичної діяльності 3. Пеленського в умовах польського владного режиму в міжвоєнний період XX ст.

Виклад основного матеріалу. 3. Пеленський народився 26 січня 1890 р. у родині о. Андрія Пеленського, пароха Лисятич (біля Стрия), та Меланії Раковської [1, с. 1]. Зиновій закінчив гімназію в Коломиї, після чого навчався на юридичному факультеті в університетах Львова та Відня. У роки національно-визвольних змагань та польсько-української війни (1918-1919), а саме наприкінці 1918 р. 3. Пеленський повернувся до Галичини і «почав працювати як господарський знавець» в уряді Західної Області Української Народної Республіки (ЗО УНР). Згодом був направлений до Праги з дипломатичною місією, після чого вступив до Української Галицької Армії (УГА) та перейшов із нею Збруч. «Там перебув він ціле пекло того часу, хворував на тиф та зносив усі злидні», - із сумом констатував його товариш Василь Мудрий [2, с. 1].

Після завершення польсько-української війни 3. Пеленський залишився у Львові та почав працювати на «кооперативній ниві» - організував кооперативи, почав брати активну участь у громадянськополітичному житті, став членом Головного Виділу «Просвіти», займався журналістикою. У 1927 р. він остаточно зосереджується на роботі в РСУК (головний редактор «Господарсько-кооперативного Часопису», референт пропаганди цього товариства) [3, с. 182], із 1930 р. - посол польського парламенту від Українського національно-демократичного об'єднання (УНДО).

У цей період, як писав часопис «Холмська земля», «терен діяльності Пеленського сягав нераз далеко поза границі наших земель» [4, с. 4]. У 1931 р. 3. Пеленський, будучи уже послом Української парламентської репрезентації (УПР), вперше взяв участь у роботі VII Конгресу національних меншин у Женеві [5, с. 2]. Відкрив Конгрес Й. Вільфан промовою, в якій проаналізував тогочасну ситуацію у світі. Голова Конгресу надіслав привітання відсутнім членам президії, зокрема Д. Левицькому. Водночас 3. Пеленський наголосив, що тогочасна Європа не вирішить питання роззброєння аж доти, доки не вирішить проблеми національних меншин. Його позиція зрештою була розкритикована головою Конгресу Й. Вільфаном [6, с. 2].

Другий день роботи Конгресу присвячений розгляду питань національних меншин. Зокрема, Е. Амменде у своєму виступі поділився з учасниками Конгресу досвідом запровадження в Естонії культурної автономії для національних меншин [7, с. 89]. В останній день роботи Конгресу (31 серпня) на порядку денному нарад було декілька важливих питань, з-поміж яких - «роззброєння, безпечність і нерозв'язанісгь національного домагання» [8, с. 2]. 3 цього приводу «Діло» писало: «Перший промовляє німецький посол з Варшави п. Шіман (німець), далі говорили Беседняк (колишній словінський посол в італійському парламенті), катальонець (посол до мадридського парляменту), мадяр (з Югославіі) $<\ldots>>$ Всі вони абсолютно повторюють відомі аргументи проти війни і за роззброєння. Живіший тон у трохи академічну дебету вносить український промовець, посол Пеленський. Вже сама обставина, що бесідник не читає, а говорить із пам'яти симпатично настроює слухачів» [8, с. 2].

Журналісти «Діла», зокрема, зазначали: «Теперішня Европа, каже бесідник [3. Пеленський - авт.], заповнена спорохнявілими будівлями державними і трохи не всі існуючі держави важко нездужають наслідком нерозв' язання національних питань. Се одне з питань цих найважніших українське». 3. Пеленський констатував, що «український нарід, якому відмовлено права на самоозначення, з права цього не зрікся. Всякі говорення про роззброєння так довго звішаться безнадійними, поки національні справи не будуть справедливо й оконечно полагоджені» $[8$, с. 2]. «Діло» писало, що «ледви п. Пеленський серед рясних оплесків зійшов з трибуни, коли туди вскочив варшавський «русский» Пімонов і зворушеним голосом відчитав заяву свого обурення з приводу смерті пол. Голувка, приписуючи вбивство «українським терористам». Звідки він це знав, святі знають. Це безосновність твердження» [8, с. 2].

Додамо, що для вирішення українського питання на Конгресі була скликана спеціальна нарада (Вільфан - словенець з Італії, Шліман - німець із Латвії, Курчинський (росіянин), 3. Пеленський). «Діло» інформувало галичан про підсумки наради: «Розмова тревала годину. п. Вільфан звернув голові Союзу Народів увагу на важке положення національних меншин і на небезпеку неполагодження національних питань для мира Европи, тай пригадав голові, що багато важних меншинних жалоб до Союзу Народів досі жде полагоди на дармо. Так нпр. вже швидко буде рік цілий від українських жалоб у справі подій 
з осені м. р. у Східній Галичині, а про ефективну полагоду їх Союзом Народів досі не чувати... Присутній на розмові посол Пеленський подав голові кілька подробиць до тієї історії тай заповів доставити йому ще декілька нових. У ході розмови п. Леру виявив і розуміння меншинних питань, і доволі добру поінформованість і цікавість далі цим питанням присвячу ва ти пильну увагу. Застерігся при цьому, що говорив це тільки своїм іменем, а не як часовий президент Союзу Народів» $[9$, с. 1$]$.

28 червня - 1 липня 1932 р. у Відні відбувся VIII Конгрес національних меншин. У перший день його роботи виступив представник українців 3. Пеленський, який охарактеризував становище українців як територіальної національної більшості в Західній Україні та ставлення розв'язання українського питання [10, с. 2]. Закликаючи національні меншини в Європі до солідарності, представник УНДО наголосив: «Нашим найпалкішим бажанням $\epsilon$, щоби наші здобули собі своєю достойною працею пошану і моральний авторитет у цілім світі. Повага нашої організації хай витисне свою печать на обличчі політичного світу і хай послужить на користь поступу та здійснення справедливого співжиття народів і держав» [11, с. 2].

Окрему увагу варто зосередити на постаті 3. Пеленського. На Конгресі він виголосив Заяву, яка викликала чимало дискусій на міжнародному форумі. «Пане президенте і Високий Конгресе! - почав 3. Пеленський. - Нав'язуючи до наших попередніх заяв, коли ми, українці, беремо від літ активну участь в европейських конгресах національностей і разом із численними іншими заступленими тут народами, солідарно домагаємося дотримання та розбудови охорони національних меншин, то проте ні на один момент не забуваємо, що вимоги і права нашого народу далеко переступають рямці меншинної охорони, бо: 1) в більшости українських країв, що прилучені до чужонаціональних держав, ми не є меншістю, лише творимо безоглядну більшість місцевого населення, а саме у Сх. Галичині, на Волині і Поліссі в Польщі, а далі в українській частині Буковини та Бесарабії в Румунії і на українській території в Чехословаччині у т. зв. Закарпатті; 2) значні українські землі, як, напр. ,Галичина і Закарпаття крім загальних постанов про охорону меншин мають ще у міжнародньому праві загарантовані цілком окремі права, затверджені міжнародніми договорами. Це торкається права Сх. Галичини і Закарпаття до автономного устрою і це право підписали великі держави разом із державами заінтересованими» [12, с. 4].

3. Пеленський зауважував, що «всупереч цьому зобов'язанню дотичні держави цього нашого права не здійснили. То му підносимо тут також як на інших місцях як найрішучіше наш голос не тільки за найповнішим здійсненням меншиневих законів супроти нас, але також за виконанням загарантованих у міжнародних договорах права наших країв на автономію в дотичних державах» [12, с. 4].

Представник української делегації констатував: «Якщо згадуємо сьогодні з вдячністю виявлене нам моральне співчуття і підтримку у зв'язку з відомими поліями з осені 1930 р. (т. зв. пацифікація), то одночасно звертаємося до Вас із проханням підтримати нас солідарно також у наших змаганнях добути згадані вище загарантовані нам міжнар. умовами права, так як це ми готові зі щирої душі підтримати змагання інших на родів. Усе, що ми бачимо нині тут у Відні, як також у Женеві, Льозанні та інших місцях, вказує нам, що грядуть нові часи, овіяні новим духом, а саме: духом солідарности, який починає охоплювати краї та народи. Вкінці та остаточно мусить затріюмфувати право перед «силою» [12, с. 4].

Завершуючи свою доповідь, 3. Пеленський зауважив: «При розбудові цього нового духа теперішнього часу наші конгреси національностей співпрацюють 3 особливою енергією. 3 задоволенням та оправданою гордістю можемо вже нині ствердити, що наша праця, як вказує на це поважна дебата в англ. палаті льордів, не остає без наслідків. Одначе ми підемо у своїх бажаннях ще дальше. Цим нашим найпалкішим бажанням $\epsilon$, щоби наші конгреси здобули собі своєю достойною працею пошану і моральний авторитет у цілому світі. Повага нашої організації хай ви тисне свою печать на обличчі політичного світу і хай послужить на користь поступу та здійснення справедливого співжиття народів і держав» [12, с. 4].

Українська делегація у складі 3. Пеленського, М. Рудницької (Польща), В. Залозенського, Ю. Сербенюка (Румунія) на IX Конгресі (1933 р.) внесла до розгляду питання про голод в УСРР, що стало одним із першочергових питань порядку денного [13, с. 3]. Зазначимо, що напередодні початку роботи Конгресу генеральний секретар Конгресу Е. Амменде підготував для газети «Діло» статтю, яка присвячувалась голодомору. «Це не простий випадок, що я як генеральний секретар Європейського Конгресу Національностей, який об'єднує кругло 40 мільйонів європейців, підіймаюсь отсього труду, щоби світові з'ясувати нечувані страхіття голодової катастрофи в Радянськім Союзі, - зазначав він. - Адже на його пограниччі мешкають численні народи, обняті Конгрессом: українці, білоруси, литовці й інші. Вони, очевидно, мають докладні дані про положення їх братів по тій стороні кордону, як і взагалі про все те, що діється на широких хліборобських землях Союзу. Мало того, що границя щільно замкнена і сильно бережена густо розставленими російськими військовими частинами, все таки передістаються 
сюди голодом гнані людські жертви. Головно вздовж водних границь Дністра і Збруча стали ті втечі трохи не щоденним явищем» [14, с. 2]. Е. Амменде зазначав, що «їх оповідання про голодові страхіття підтверджують наочні свідки з-за кордону, яким вдалося об'їхати й оглянути північний Кавказ, Кубань, Надволжанську Німецьку Республіку, а особливо Україну» [14, с. 2].

23 вересня делегація Конгресу національних меншин на чолі з Й. Вільфаном зустрілася з головою Ради Ліги Націй Л. Мовінклем, якому вручено резолюції останнього Конгресу. Учасник делегації 3. Пеленський подякував від імені українців представникам Норвегії за їхнє прихильне ставлення до справ, які були на порядку дня Ліги Націй. Делегація звернула увагу на процедуру розгляду петицій меншин у Лізі Націй, на потребу ії змінити та необхідність створення окремої комісії для вирішення справ національних меншин [15, арк. 19]. Того ж дня 3. Пеленський оптимістично писав В. Мудрому із Женеви: «Загалом є таке враження, що всі вже знають про голод на Україні, однак треба ще буде багато ужити заходів, щоби публічна опінія змусила офіціяльні чинники до рятункової акції» [16].

Після тривалої перерви 3. Пеленський узяв участь у роботі XII Конгресу національних меншин, який відбувся 16-17 вересня 1936 р. у Женеві. Свою роботу Конгрес розпочав вшануванням пам’яті покійного генерального секретаря Е. Амменде. Серед учасників форуму були представники німців, українців, угорців, болгарів, хорватів, словенців, чехів і словаків з Австрії, росіян та шведів з Естонії та Румунії [17, с. 1]. Напередодні скликання редактор «Журналь де Женев» Е. Бріке у статті, присвяченій роботі Конгресу, звернув увагу на позицію українців, зауваживши, що «їх занепокоєння дуже велике - світ лишається байдужим на тяжку долю 35 міліонів їх братів у Совітській Україні, загрожених московською екстермінаційною політикою» $[17$, с. 1]. Окрім цього, автор статті вказав актуальність національного питання, адже 1914 року саме це стало однією з причин початку Першої світової війни [17, с. 1].

Двома основними питаннями Конгресу були: 1) право на існування національних груп у державах Європи; 2) реформа Ліги Націй і національні меншини. Основою для дискусії над першим питанням була промова представника німців Данії - Ш. Зодера, який обгрунтував права національних меншин. У дискусії виступив 3. Пеленський, зауваживши: «На превеликий жаль, доводиться мені промовляти на XII з черги нашім Конгресі про право на життя національних груп у державах Європи, а не про поширення та поглиблення цих прав» $[17$, с. 1]. Він розкритикував примітку на запрошенні на Конгрес, де йшлося про відсутність питання становища окремих національних меншин у державах у порядку денному. Не міг оминути представник УНДО й УПР становища українців у СРСР: «Московський уряд не лише сповнює засобами національно-політичного терору розвиток української нації < ..>, але й фізично винищує цілі частини української нації, якої засимілювати не має надії», -зазначав 3. Пеленський $[17$, с. 1]. Політик запропонував Конгресу виступити посередником між національними меншинами і державними представниками та узгоджувати відносини між обома сторонами.

Телеграфічні повідомлення німецького прес-бюро та швейцарської телеграфічної агенції цитували уривки промови 3. Пеленського про становище українців в СРСР [17, с. 1]. «Діло» 3 цього приводу писало: «Його промова, нагороджена рясними оплесками, викликала велике зацікавлення Конгресу, а зокрема, заступленої на нім преси. У телеграфічних звістках Німецького Пресового Бюра та Швейцарсько Телеграфічної Агенції особливо підкреслено те, що український Делегат говорив про страшну ситуацію української нації під пануванням Москви та про отруйні величи московського уряду і Комінтерну на відносини між урядами та національними меншинами у ріжних державах Европи, зокрема у Польщі. Такий підхід актуальний остільки, що руїнницька акція на терені міжнаціональних відносин у ріжних державах Европи це справді одна з найповажніших перешкод на шляху миру...» [17, с. 1].

13-16 липня 1937 р. в Лондоні розпочав роботу XIII Конгрес національних меншин. Головною темою дискусій лондонських засідань стала реформа Ліги Націй. Окрім цього, йшлося про пошанування прав національних меншин як про основу співжиття європейських народів, окреслено вплив самоврядування на культурне і господарське життя національних меншин $[18$, с. 2]. На конгресі з доповіддю виступив 3. Пеленський. «Діло» так передало основні тези його виступу: «Провідною думкою реферату пос. 3. Пеленського була самоуправа. Пос. Пеленський виказував на основі історії Англії, як дуже придається самоуправа, щоб на ній сперти керму і управу складних державних справ. Зокрема, самоуправа надається до пристосування до національних меншин. Вони ще більше вимагають такої самоуправи, бо змагають до їі найвищої форми, до власної держави. Опісля промовець спинився над поодинокими ділянками громадського культурного і господарського життя, що їх нарід може осягнути найкраще при допомозі самоуправи. Це торкається не лише територіальних меншин, які мають сякий-такий доступ до самоуправи, але також до персональних меншин поєднаних у професійних, ремісничих, культурних і т. п. організаціях. Вкінці неостаннє місце займає теж Церква, що відограє велику історичну ролю не лише в релігійному, але також і національному житті українського народу» [19, с. 3]. 
Українська делегація (3. Пеленський, В. Залозенський, В. Мудрий) підтримала дві ухвали. Перша («Реформа Ліги націй і прав національних меншин») констатувала, що «приняті Лігою Націй гарантії у справі здійснення міжнародної охорони національних меншин залишились майже не виконані і минулого року» $[19$, с. 3]. Конгрес пропонував Лізі Націй «зайнятися тим, щоби здійснено права національних меншин і щоби при нагоді реформи Ліги Націй подбати про дійсне наладнання і пристосування міжнародніх прав та міжнародної охорони національних меншин» [19, с. 3].

Останній XIV Конгрес національних меншин (25-26 серпня 1938 р.) пройшов у Стокгольмі і вирішував такі питання: 1) національна політика у повоєнний період; 2) загроза миру «з причини пошанування прав національностей; 3) домагання національностей зі становища етики та їхнє значіння для розвитку європейського права». Українська делегація (3. Пеленський, В. Залозецький, О. Марітчак, В. Мудрий) брала активну участь у розгляді цих питань. У резолюціях Конгресу стверджено, що «загальне положення національностей в Європі погіршується дальше в застрашневий спосіб. Майже всім національностям загрожує потрійна небезпека: остаточна затрата політичного значіння, господарське зубожіння та зменшення числа населення через асиміляцію, вимушене переселення та перепони при витворенні національно свідомих кляс» [20, с. 3].

Конгрес звернувся до урядів європейських держав із закликом провести зміни в напрямі реалізації політичної та культурної рівноправності всіх національностей. Учасники Конгресу зверталися також у своїх резолюціях до великодержав, які відігравали провідну роль у Лізі Націй: «Конгрес стверджує, що великодержави, творячи в рр. 1919-1920 у Лізі Націй контрольний орган для справ національних меншин, вийняли себе з-під цією контролі, через це створили засаду нерівности між державами і довели до краху, наглядним доказом якого було у 1934 р. виповідження Польщею її зобов'язань дотично національних меншин» [20, с. 3].

Висновки. У 1930-х рр. 3. Пеленський брав участь у роботі практично усіх Конгресів національних меншин. Діючи в рамках програмних засад УНДО, він незмінно відстоював право українського народу на власну державу, засуджував національно-культурну політику Другої Речі Посполитої. Виступи українського політика на міжнародній арені знаходили відгомін в європейській пресі, жваво обговорювалися українським суспільством, яке схвально оцінювало основні його тези.

1. Забута могила. Наше слово. 2012. 19 лютого. С. 1.

Література:

2. Помер Зиновій Пеленський. Рідна земля. 1943. 11 листопада. С. 1.

3. Гелей Т., Гелей С. Зиновій Пеленський. Українські кооператори (Історичні нариси): У 3-х кн. / За ред. С. Гелея. Львів : Вид-во Львівської комерційної академії, 2007. Кн. 3. 380 с.

4. Памяті 3. Пеленського. Холмська земля. 1944. 30 січня. С. 4.

5. [Конгрес національних меншин]. Діло. 1931. 28 серпня. С. 2.

6. На Конгресі Національних меншин. Діло. 1931. 9 вересня. С. 2.

7. Ротбарт М. Евальд Амменде и организация европейских конгрессов национальних меншинств. Германия и Прибалтика. 1978. Вып. 5. С. 88-96.

8. [Конгрес національних меншин]. 1931. Діло. 1931. 5 вересня. С. 2.

9. Мобілізація і маневри (Від нашого кореспондента.). Діло. 1931. 9 вересня. С. 1.

10. VIII Конгрес національностей. Діло. 1932. 9 липня. С. 2.

11. VIII Конгрес національностей. Діло. 1932. 10 липня. С. 2.

12. Українці на VIII. Конгресі Національностей. Діло. 1932. 9 липня. С. 4.

13. IX Конгрес національностей. Діло. 1933. 20 вересня. С. 3.

14. Конгрес національностей. Діло. 1933. 28 липня. С. 1-2.

15. Державний архів Львівської області. Ф. 11. Оп. 29. Спр. 6531. Арк. 19.

16. Дерев'яний I. Голодомор та Свропа: уроки демократії. URL: http://incognita.day.kyiv.ua/golodomor-ta-yevropa-urokidemokratiyi.html

17. ХІІ. Конгрес національностей у Женеві. Діло. 1936. 26 вересня. С. 1.

18. Конгрес національностей. Діло. 1937. 21 липня. С. 2.

19. Етичні підстави національних рухів та самоуправа, як форма вияву. Зміст реферату українського посла Зеновія Пеленського та білорусина о. А. Станкевіча на конгресі меншин у Льондоні. Діло. 1937. 21 липня. С. 3.

20. Конгрес національностей. Діло. 1938. 6 вересня. С. 3. 